\title{
INTEGRASI PENDEKATAN ANALYTIC NETWORK PROCESS DAN STRUCTURAL EQUATION MODELING UNTUK PENGUKURAN BULLYING DI TEMPAT KERJA BERBASIS GENDER MENGGUNAKAN SISTEM PAKAR
}

\author{
${ }^{1)}$ Ira Puspita Sari, ${ }^{2)}$ Anip Febtriko, ${ }^{3)}$ Tri Rahayuningsih, ${ }^{4)}$ Adrian Adi Putra \\ 1)2) Jurusan Teknik Informatika, Fakultas Teknik, Universitas Abdurrab, Pekanbaru \\ Jln. Riau Ujung No. 73, Kota Pekanbaru, 28292, Indonesia \\ 3)4) Jurusan Psikologi, Fakultas Psikologi, Universitas Abdurrab, Pekanbaru \\ Jln. Riau Ujung No. 73, Kota Pekanbaru, 28292, Indonesia \\ E-Mail: ira.puspita.sari@univrab.ac.id,tri.rahayuningsih@univrab.ac.id,anip.febtriko@univrab.ac.id, \\ adrian.adi@univrab.ac.id
}

\begin{abstract}
ABSTRAK
Intimidasi atau yang dikenal dengan istilah bullying, dalam penelitian di tempat kerja menghasilkan dampak kesehatan mental yang merugikan. Namun, sedikit yang mengungkap perbedaan jenis kelamin yang menghubungkan perilaku bullying di tempat kerja dan kesehatan mental yang buruk. Penindasan di dunia maya atau cyberbullying di tempat kerja pun ditemukan sebagai fenomena yang berkembang dengan akibat fatal, mulai dari menimbulkan ketegangan mental karyawan dan kepuasan kerja yang rendah, hingga iklim organisasi yang bermusuhan. Pelaku cyberbullying di tempat kerja ini membenarkan perilaku bullying mereka dan hasil fitur komunikasi cyber ternyata mempengaruhi perilaku cyberbullying di tempat kerja. Lebih dari satu diantara sepuluh responden mengalami bullying di tempat kerja menunjukkan masalah absensi. Metode penelitian yang digunakan adalah dengan metode Analytic Network process (ANP) dan Structural Equation Modeling (SEM) yang diaplikasikan menggunakan Sistem Pakar (Expert System). Jumlah butir aitem pada alat ukur ini pada awalnya sebanyak 29 butir aitem pertanyaan, kemudian berdasarkan analisa-analisa validitas konstruk didapatkan butir yang valid sebanyak 28 butir aitem. Penelitian ini merupakan uji korelasi dengan Variabel Y bullying di tempat kerja, serta Variabel X1 Gender, X2 Usia, X3 Masa Kerja, dan X4 Jenis Profesi. Juga dilakukan uji beda antara persepsi karyawan perempuan dengan laki-laki terhadap variable bullying di tempat kerja. Penelitian ini dibutuhkan untuk dapat mencegah perilaku kekerasan dalam dunia kerja terutama pada perempuan.
\end{abstract}

Kata kunci: Intimidasi, gender, sistem pakar

\begin{abstract}
Intimidation or what is known as bullying, in research at work produces adverse mental health effects. However, few reveal gender differences that link bullying behavior in the workplace and poor mental health. Oppression in cyberspace or cyberbullying in the workplace was found as a phenomenon that developed with fatal consequences, ranging from causing employee mental tension and low job satisfaction, to hostile organizational climate. The perpetrators of cyberbullying in the workplace justify their bullying behavior and the results of the cyber communication feature apparently influence cyberbullying behavior in the workplace. More than one in ten respondents experiencing bullying at work shows a problem with attendance. The research method used is the Analytic Network process (ANP) and Structural Equation Modeling (SEM) methods that are applied using the Expert System. The number of items in this measuring instrument is initially 29 items in question, then based on analyzes of construct validity, there are 28 items valid. This study is a correlation test with Y bullying variables in the workplace, as well as X1 Gender Variables, X2 Age, X3 Work Period, and X4 Professional Type. Also conducted a different test between the perceptions of female employees and men on the variable bullying in the workplace. This research is needed to be able to prevent violent behavior in the world of work, especially in women.
\end{abstract}

Keywords: Bullying, gender, expert system

\section{PENDAHULUAN}

Salah satu faktor yang relevan dengan lingkungan kerja adalah bullying atau intimidasi. Lebih dari satu diantara sepuluh responden mengalami bullying di tempat kerja menunjukkan masalah absensi. Jika dampak bullying mengarah kepada masalah kesehatan yang parah seperti depresi, ada kemungkinan individu akan menderita sakit jangka panjang, yang menghambat produktifitas karyawan dan 
kinerja organisasi. Bullying melibatkan perilaku negatif dan menyebabkan beberapa kerusakan pada target yang diintimidasi. Mulai dari yang terselubung, komentar sinis, hingga yang agresif seperti barang dilempar atau ancaman fisik, diganggu atasan atau rekan kerja, muncul gejala fisik dan psikologis termasuk stres dan kecemasan tentang pekerjaan, depresi, kehilangan kepercayaan diri, kepuasan kerja yang menurun dan penurunan komitmen organisasi. Penelitian tentang bullying ini penting untuk diketahui agar organisasi dapat menanganinya dengan baik, salah satunya bisa melalui pengukuran bullying di tempat kerja. [1]

Banyak organisasi mengadopsi pendekatan yang tidak dapat digunakan untuk menilai status pelaku atau target bullying, dan tingkat risiko perilaku bullying secara kuantitatif, yang terlihat langsung hasil pengukurannya untuk dapat membantu keputusan bagian manajemen sumber daya manusia (SDM) seperti dalam bentuk kemudahan yang ditawarkan aplikasi web. Metode Analytic Network Process (ANP) dapat menangani inter-dependensi dalam sebuah klaster dan diantara berbagai klaster. Metode ANP menyimpan konsep inti dari metode AHP, yang membagi sistem keputusan menjadi struktur hierarkis, dan percaya bahwa kriteria dalam tingkat yang lebih rendah didominasi oleh kriteria tingkat yang lebih tinggi yang berdekatan. Metode ANP sudah pernah digunakan dalam penelitian sebelumnya untuk membantu keputusan bidang SDM, seperti unuk mengukur organizational citizenship behavior, penilaian keamanan kerja menggunakan metode ANP dalam aplikasi sistem pakar untuk seleksi karyawan.

Model teoritis bahwa persepsi bullying di tempat kerja dapat mempengaruhi gejala psikologis pernah diuji pada tingkat kausalitas oleh model persamaan struktural SEM (Structural Equation Modeling), juga model terpisah untuk gender dan ras dalam memprediksi target bullying. Gender memiliki efek interaksi yang penting pada penilaian persepsi bullying di tempat kerja. Namun, belum ditemukan penelitian tentang bullying yang menggunakan integrasi pendekatan ANP dan SEM, sementara organisasi harus memastikan bahwa tempat bekerjanya telah berupaya mencegah terjadinya bullying dan membantu karyawan yang telah diganggu. Oleh karena itu, tujuan penelitian ini adalah untuk mengetahui bagaimana analisa kedua metode tersebut dalam sistem pakar untuk mengukur bullying di tempat kerja berdasarkan persepsi gender. Diharapkan manfaat penelitian dasar pemula ini dapat menjadi pengembangan keilmuan teknologi informasi sebagai pendukung kebijakan sosial humaniora yakni mencegah perilaku kekerasan dalam dunia kerja terutama pada perempuan. [2]

\section{Bullying di Tempat Kerja}

Bullying di tempat kerja adalah tentang tindakan berulang-ulang dan praktek yang diarahkan terhadap satu atau lebih pekerja, yang tidak diinginkan oleh korban, yang mungkin dilakukan dengan sengaja atau tidak sadar, tetapi jelas menyebabkan penghinaan, pelanggaran dan kesusahan, dapat mengganggu kinerja, serta menyebabkan lingkungan kerja menjadi tidak menyenangkan. Komponen yang biasa digunakan oleh para peneliti dan praktisi termasuk terjadinya perilaku kerja yang berbahaya dan negatif. Selain itu, definisi awam sering memasukkan tema keadilan dan rasa hormat. Salah satu ciri umum untuk semua definisi bullying di tempat kerja adalah pengalaman negatif verbal atau tingkah laku non-verbal. [3] 
Rayner dan Hoel mengelompokkan perilaku bullying di tempat kerja ke dalam bentukbentuk sebagai berikut :

a. Ancaman pada status profesional, seperti mempermalukan di depan publik, menyalahkan karena kurangnya usaha.

b. Ancaman pada pribadi, seperti memberi nama ledekan, menghina, mengintimidasi dan merendahkan seseorang karena usianya.

c. Mengisolasi, seperti mencegah pegawai mengakses kesempatan, mengisolasi secara fisik dan sosial dan menahan informasi.

d. Beban kerja yang berlebihan, seperti tekanan yang terus menerus, batas waktu yang tidak mungkin terpenuhi.

e. Perbuatan yang menyebabkan ketidakstabilan, seperti memberikan tugas yang tidak berguna, penghapusan tanggung jawab, mengingat ulang kesalahan dan menyiapkan untuk gagal.

Ada berbagai alasan yang menyebabkan seseorang melakukan perilaku bullying di tempat kerja, yaitu :

a) Kekuasaan; seseorang dapat menggunakan posisi kekuasaan atau dominasi fisik mereka atas orang lain yang dianggap lebih lemah.

b) Penghargaan diri; pelaku bullying mengintimidasi dan merendahkan orang lain dengan tujuan untuk meningkatkan harga diri dan kepercayaan diri untuk membantu mengatasi perasaan tidak mampu pada diri mereka sendiri.

c) Perbedaan; seorang individu atau kelompok dapat menjadi target intimidasi dan bullying di tempat kerja karena orang lain menganggap mereka sebagai seseorang yang baru atau berbeda.

d) Ancaman; beberapa orang menggertak orang lain karena orang lain dianggap sebagai ancaman bagi mereka baik secara pribadi atau posisi mereka dalam perusahaan. e) Budaya Organisasi yang sering ditunjukkan oleh adanya nilai-nilai, keyakinan dan apa yang dianggap perilaku normal. Karyawan mungkin menemukan diri mereka dalam budaya negatif di mana perilaku yang tidak pantas dan sikap didorong atau dibiarkan oleh manajemen dan

intimidasi dipandang sebagai perilaku normal untuk mayoritas orang di tempat kerja.

f) Faktor Organisasi ; orang mungkin melecehkan atau menggertak orang lain karena ketidakpuasan dengan peraturan organisasi. Faktor-faktor yang termasuk di dalamnya adalah ketidakamanan kerja, restrukturisasi atau perampingan, adanya perubahan seperti manajer atau supervisor baru, daftar nama baru atau prosedur baru, perubahan kepemilikan, pengenalan teknologi baru, dukungan atau pelatihan yang tidak memadai, kurangnya keterampilan dan praktek dalam manajemen, pengaturan pekerjaan yang berarti individu atau kelompok kerja bekerja secara terpisah dari supervisor di tempat kerja.

g) Kontak dengan klien atau pelanggan dalam beberapa industri bisa mengancam atau mengganggu karyawan. Pelatihan staf dalam menangani pelanggan yang sulit, prosedur penarikan dari situasi yang berisiko dan akses untuk konseling atau pembekalan semua dapat membantu untuk mengendalikan risiko ini. [1]

\section{Pengukuran bullying di tempat kerja berbasis gender}

Penelitian yang telah menghasilkan skala bullying di tempat kerja didasarkan pada persepsi karyawan tentang bullying tempat kerja. Frekuensi nyata bullying di tempat kerja ini tidak dapat ditentukan. Sampel nya hanya pekerja di bidang kesehatan, dengan demikian perbandingan lintas lapangan kerja tidak 
dapat dilakukan dalam penelitian tersebut. Instrumen bullying di tempat kerja dikembangkan pada tahun 2000-an menggunakan model pengukuran reflektif, tetapi properti psikometri mereka tidak mencukupi dan model pengukuran dipertanyakan, sehingga disarankan taksonomi yang dimodifikasi harus diverifikasi dan menyusun instrumen yang lebih dapat diandalkan. Gender memiliki efek interaksi yang penting, bahwa manajer perempuan lebih banyak mengalami bullying daripada manajer laki-laki. Pekerja wanita yang di-bully memiliki ketidakhadiran dua kali lipat dibandingkan teman kerja wanita yang tidak mengalami bullying karena pria dan wanita memiliki strategi coping atau penyelesaian masalah dengan cara yang berbeda. Sasaran bullying paling sering terjadi pada diskriminasi gender, pelecehan seksual dan rasial, sementara dampak bullying lebih berat pada karyawan perempuan. [2]

\section{Pendekatan ANP dan SEM}

Penggunaan ANP pada domain baru dalam konteks negara berkembang berguna untuk penelitian dan praktik sistem pendukung keputusan (DSS). Kebaruan penelitian ini berasal dari ketelitian metodologisnya, yang memungkinkan triangulasi dengan menggabungkan penelitian kualitatif terhadap metodologi ANP dalam bentuk penilaian pada wawancara mendalam dan penggunaan diskusi kelompok yang memungkinkan peneliti memahami konsep bullying di tempat kerja, juga motif perilaku bullying. Ini merupakan gabungan pendekatan teoritis dengan nilai pengukuran yang sebenarnya melalui penggunaan ANP, sehingga menghasilkan model pengukuran bullying di tempat kerja yang dapat digunakan dalam penelitian lebih lanjut, maupun dalam praktik karena akan disajikan dengan menggunakan sistem pakar dalam bentuk aplikasi web.
Meskipun ANP adalah metode yang kuat dalam hal penilaian, namun memiliki beberapa keterbatasan. Dalam ANP, pekerjaan yang paling penting adalah membuat matriks perbandingan berpasangan timbal balik. Perbandingan antara dua alternatif yang diberikan dilakukan menggunakan pendapat ahli, perasaan, pengalaman, dan intuisi. Karena ANP sangat bergantung pada penilaian ahli, hasil yang diperoleh terbatas secara kognitif dan bias psikologis para ahli. Dengan demikian, dalam menyimpulkan analisa harus optimal dan hatihati, sehingga pendekatan SEM dibutuhkan sebagai analisa tambahan. Alasannya, netralisasi konsep bullying di tempat kerja yang multidimensional sulit untuk diidentifikasi ketika menggunakan metode berbasis kovarians, metode SEM bekerja baik dalam memprediksi dan membantu pengembangan teori untuk penelitian seperti studi ini, serta dapat menangani data yang sangat tidak normal secara efisien. [2]

\section{Pengertian Sistem Pakar}

Menurut Budiharto (2014), sistem pakar (Expert System) adalah program komputer yang menyimulasi penilaian dan perilaku manusia atau organisasi yang memiliki pengetahuan dan pengalaman ahli dalam bidang tertentu.

Menurut Merlina dan Rahmat (2012), ada beberapa pengertian sistem pakar menurut para ahli:

1. Menurut Martin dan Oxman, Sistem Pakar adalah sistem yang berbasis komputer yang menggunakan pengetahuan, fakta, dan teknik penalaran dalam memecahkan masalah yang biasanya dapat diselesaikan oleh seorang pakar dalam bidang tertentu.

2. Menurut Ignozio, Sistem Pakar merupakan bidang yang didirikan oleh sistem berbasis pengetahuan 
(Knowledge Base System), memungkinkan komputer dapat berfikir dan mengambil keputusan dari sekumpulan kaidah.

3. Menurut John Durkin, Sistem Pakar adalah program komputer yang didesign untuk meniru kemampuan memecahkan masalah dari seorang pakar.

4. Menurut Giarratano dan Filey, Sistem Pakar adalah salah satu cabang kecerdasan buatan yang menggunakan pengetahuan-pengetahuan khusus yang dimiliki oleh seorang ahli untuk menyelesaikan suatu masalah tertentu. [4]

\section{a. Karakteristik Sistem Pakar}

Adapun karakteristik sistem pakar (Budiharto, 2014), antara lain:

1. High performace (berkinerja tinggi).

2. Adequate response time (mampu memberikan jawaban tepat waktu).

3. Good reliability (handal).

4. Understandable (mudah dimengerti). [3]

\section{b. Kelebihan dan Kekurangan Sistem Pakar}

Sistem pakar memiliki kelebihan dan kekurangan:

1. Kelebihan Sistem Pakar

Menurut Budiharto (2014), sistem pakar mempunyai kelebihan sebagai berikut:

a. Sistem pakar dapat bertindak sebagai konsultan, instruktur, atau pasangan/rekan.

b. Meningkatkan availability atau kepakaran tersedia pada semua perangkat komputer.

c. Mengurangi bahaya.

d. Permanen.

e. Pengetahuan dapat tidak lengkap, namun keahlian dapat diperluas sesuai kebutuhan. Program konvensional harus "lengkap" sebelum mereka dapat digunakan.

f. Database yang cerdas, sistem pakar dapat digunakan untuk mengakses database secara cerdas, misalnya data mining.

\section{Kekurangan Sistem Pakar}

Disamping memiliki beberapa keuntungan, sistem pakar juga memiliki beberapa kelemahan (Arhami, 2005), diantaranya adalah:

a. Masalah dalam mendapatkan pengetahuan dimana pengetahuan tidak selalu bisa didapatkan dengan mudah, karena kadangkala pakar dari masalah yang kita buat tidak ada, dan kalaupun ada kadang-kadang pendekatan yang dimiliki oleh pakar berbeda-beda.

b. Untuk membuat suatu sistem pakar yang benar-benar berkualitas tinggi sangatlah sulit dan memerlukan biaya yang sangat besar untuk pengembangan dan pemeliharaannya.

c. Boleh jadi sistem tidak dapat membuat keputusan.

d. Sistem pakar tidaklah 100\% menguntungkan, walaupun seorang tetap tidak sempurna atau tidak selalu benar. Oleh karena itu perlu diuji ulang secara teliti sebelum digunakan. Dalam hal ini peran manusia tetap merupakan faktor dominan. [4]

\section{METODE}

\section{Variabel Penelitian}

Penelitian ini merupakan uji korelasi dengan Variabel Y bullying di tempat kerja, serta Variabel X1 Gender, X2 Usia, X3 Masa Kerja, dan X4 Jenis Profesi. Juga dilakukan uji beda beda antara persepsi karyawan perempuan dengan laki-laki terhadap variable bullying di tempat kerja. 


\section{Subjek Penelitian}

Subjek dalam penelitian ini adalah karyawan laki-laki dan perempuan yang ada di Pekanbaru dari beragam profesi dan usia. Jumlah subjek sebanyak 83 orang sebagai sampling yang sudah ada. Adapun metode pengambilan sampling yang akan digunakan adalah incidental sampling yaitu Teknik pengambilan sampling berdasarkan kebetulan, peneliti bertemu dengan subjek yang dapat digunakan sebagai sampel.

\section{Teknik Pengumpulan Data}

Penelitian ini dibagi dalam beberapa tahapan pengumpulan data. Baik teknik kualitatif dan kuantitatif diadopsi dalam penelitian ini untuk penataan jenis masalah yang akan diolah ANP. Sementara teknik kualitatif lebih baik dalam menangkap dan memasukkan aspekaspek tak berwujud dari situasi keputusan, sedangkan teknik kuantitatif lebih mampu merealisasikan hubungan timbal balik di antara banyak kriteria. Untuk memanfaatkan keuntungan dari kedua metode tersebut, kedua metodologi ini digabungkan dalam kerangka kerja yang sama. Domain pengetahuan tentang bullying di tempat kerja dikumpulkan dari perwakilan karyawan menggunakan teknik kualitatif, kemudian temuan dianalisis dan disusun dalam model menggunakan ANP, yang merupakan alat yang berpengaruh untuk memecahkan masalah keputusan kompleks. Karena sifatnya yang kompleks dan saling bergantung, interaksi di antara orang-orang yang berasal dari pengaturan kontekstual dan tugas tidak dapat dijelaskan oleh struktur hierarkis. Karena semua alternatif dalam model ini terkait, bobot yang menentukan keterkaitan di antara semua komponen perlu dihitung. Dengan demikian, metode ANP digunakan untuk pengaturan yang didasarkan pada perbandingan berpasangan yang sama. Dalam pengertian ini, analisis yang rumit harus dilakukan untuk mengidentifikasi peringkat dalam hal pentingnya persepsi bullying di tempat kerja. Berikut adalah langkah-langkah metodologi penelitian



Gambar 1. Pendekatan ANP dalam metode kualitatif

\section{Analisa Data}

Analisa data dalam penelitian ini diawali dengan pendekatan ANP dalam penilaian verbatim wawancara, dan pendekatan SEM untuk analisa exploratori dan konfirmatori, sehingga mendapatkan faktor-faktor yang valid dan reliabel dari alat ukur Workplace Bullying Scale (WBS). Kemudian uji hipotesis menggunakan metode analisa regresi berganda dengan membuat persamaan regresi dan menganalisa pengaruh masingmasing variabel bebas, sehingga diperoleh kesimpulan hipotesa diterima atau ditolak.

Hasil yang telah diperoleh dimasukan sebagai knowledge expert ke dalam aplikasi web sebagai dasar aturan memprediksi persepsi gender terhadap bullying di tempat kerja melalui forecasting dimensi-dimensinya, serta faktor usia, masa kerja, dan ragam profesi. Peneliti membuat sistem pakar ini menggunakan metode forward chainning. [5]

\section{HASIL}

Hasil Uji Validitas dan Reliabilitas Skala Perilaku Bullying di Tempat Kerja

Skala penelitian yang disebarkan kepada 83 orang sebagai sampling berisi 29 pernyataan dengan pilihan jawaban Sangat Sesuai (SS), 
Sesuai (S), Tidak Sesuai (TS) dan Sangat Tidak Sesuai (STS). Berikut adalah tabel skala penelitiannya.

conton :

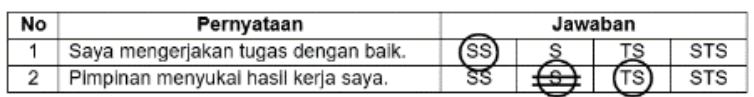

\begin{tabular}{|c|c|c|c|c|c|}
\hline No & Pernyataan & \multicolumn{4}{|c|}{ Jawaban } \\
\hline 1 & $\begin{array}{l}\text { Saya sering mengkritik pekerjaan teman } \\
\text { saya di depan umum. }\end{array}$ & ss & $S$ & TS & STS \\
\hline 2 & $\begin{array}{l}\text { Saya berani mengungkap kejelekan } \\
\text { orang lain dalam forum rapat. }\end{array}$ & ss & $\mathrm{s}$ & TS & STS \\
\hline 3 & $\begin{array}{l}\text { Saya marah bila menemukan sesuatu } \\
\text { yang tidak sesual dengan keinginan } \\
\text { saya. }\end{array}$ & ss & $s$ & TS & STS \\
\hline 4 & $\begin{array}{l}\text { Saya marah kepada rekan kerja yang } \\
\text { tidak mencapai target kerja. }\end{array}$ & & & & \\
\hline 5 & $\begin{array}{l}\text { Saya senang menjuluki teman dengan } \\
\text { sebutan jeleknya. }\end{array}$ & SS & $s$ & TS & STS \\
\hline 6 & $\begin{array}{l}\text { Saya senang mengejek teman yang lebih } \\
\text { jelek secara fisik dari saya. }\end{array}$ & SS & $\mathrm{s}$ & TS & STS \\
\hline 7 & $\begin{array}{l}\text { Saya tidak suka Jika karyawan } \\
\text { membicarakan kejelekan orang lain. }\end{array}$ & SS & $\mathrm{s}$ & TS & STS \\
\hline 8 & $\begin{array}{l}\text { Saya memusuhi rekan kerja yang tidak } \\
\text { sopan kepada saya. }\end{array}$ & ss & $\mathrm{s}$ & TS & STS \\
\hline
\end{tabular}

\begin{tabular}{|c|l|c|c|c|c|}
\hline 9 & Saya tidak suka menghina orang lain. & SS & S & TS & STS \\
\hline 10 & $\begin{array}{l}\text { Saya mengancam rekan kerja untuk } \\
\text { segera menyelesaikan pekerjaannya. }\end{array}$ & SS & S & TS & STS \\
\hline 11 & $\begin{array}{l}\text { Saya tidak berani mengancam rekan } \\
\text { kerja. }\end{array}$ & SS & S & TS & STS \\
\hline 12 & $\begin{array}{l}\text { Saya tidak menaggapi pendapat dari } \\
\text { karyawan muda. }\end{array}$ & SS & S & TS & STS \\
\hline 13 & $\begin{array}{l}\text { Saya menghargai pendapat orang lain, } \\
\text { meskipun lebih muda dari saya. }\end{array}$ & SS & S & TS & STS \\
\hline 14 & $\begin{array}{l}\text { Keluhan dari karyawan muda merupakan } \\
\text { hal yang tidak penting. }\end{array}$ & SS & S & TS & STS \\
\hline 15 & $\begin{array}{l}\text { Saya berusaha mencegah karyawan lain } \\
\text { mendapatkan bonus. }\end{array}$ & SS & S & TS & STS \\
\hline 16 & $\begin{array}{l}\text { Saya malas bertemu dengan rekan kerja } \\
\text { yang kurang saya sukai. }\end{array}$ & SS & S & TS & STS \\
\hline 17 & $\begin{array}{l}\text { Saya mengajak karyawan lain untuk } \\
\text { menjauhi rekan kerja yang tidak saya } \\
\text { sukai. }\end{array}$ & SS & S & TS & STS \\
\hline 18 & $\begin{array}{l}\text { Saya tidak mau bekerja dalam satu tim } \\
\text { dengan rekan kerja yang saya benci. }\end{array}$ & SS & S & TS & STS \\
\hline 19 & $\begin{array}{l}\text { Saya akan mengucilkan rekan kerja yang } \\
\text { tidak saya sukai. }\end{array}$ & SS & S & TS & STS \\
\hline 20 & $\begin{array}{l}\text { Saya berani membela rekan kerja yang } \\
\text { tidak melakukan kesalahan. }\end{array}$ & SS & S & TS & STS \\
\hline 21 & $\begin{array}{l}\text { Saya tidak mau memberikan informasi } \\
\text { kepada rekan kerja yang tidak saya } \\
\text { sukai. }\end{array}$ & SS & S & TS & STS \\
\hline 22 & $\begin{array}{l}\text { Saya tidak mau memberitahukan jadwal } \\
\text { apapun, kecuali jika ada yang bertanya. }\end{array}$ & SS & S & TS & STS \\
\hline 23 & $\begin{array}{l}\text { Saya memaksa rekan kerja untuk } \\
\text { mengerjakan pekerjaan saya. }\end{array}$ & SS & S & TS & STS \\
\hline 24 & $\begin{array}{l}\text { Saya memberikan pekerjaan yang sulit } \\
\text { kepada rekan kerja. }\end{array}$ & SS & S & TS & STS \\
\hline
\end{tabular}

\begin{tabular}{|c|l|c|c|c|c|}
\hline 25 & $\begin{array}{l}\text { Dengan adanya deadline waktu, } \\
\text { karyawan dapat bekerja maksimal. }\end{array}$ & SS & S & TS & STS \\
\hline 26 & $\begin{array}{l}\text { Saya selalu memberikan pekerjaan } \\
\text { kepada rekan kerja, meskipun pekerjaan } \\
\text { tersebut tidak penting. }\end{array}$ & SS & S & TS & STS \\
\hline 27 & $\begin{array}{l}\text { Jika saya melakukan kesalahan, saya } \\
\text { akan menyalahkan teman kerja saya. }\end{array}$ & SS & S & TS & STS \\
\hline 28 & $\begin{array}{l}\text { Jika melakukan kesalahan, saya akan } \\
\text { menyalahkan rekan kerja yang lain. }\end{array}$ & SS & S & TS & STS \\
\hline 29 & $\begin{array}{l}\text { Saya menyimpan dendam kepada rekan } \\
\text { kerja. }\end{array}$ & SS & S & TS & STS \\
\hline
\end{tabular}

\begin{tabular}{|c|c|c|c|}
\hline Axpek Bullying & Indikutur & $\begin{array}{c}\text { Sehargn } \\
\text { Sonkor Attem }\end{array}$ & $\begin{array}{c}\text { Jumlub } \\
\text { Sebersul } \\
\text { Nnmor Aitem }\end{array}$ \\
\hline $\begin{array}{l}\text { Ancaman pada } \\
\text { stutus } \\
\text { proTesionul }\end{array}$ & $\begin{array}{l}\text { - Mempermalukan di depan publik } \\
\text { - Menyalalkan kareca barangnya } \\
\text { usahn }\end{array}$ & $\begin{array}{c}1,2 \\
3\end{array}$ & $\begin{array}{l}2 \\
1\end{array}$ \\
\hline $\begin{array}{l}\text { Ancaman puth } \\
\text { prithadi }\end{array}$ & 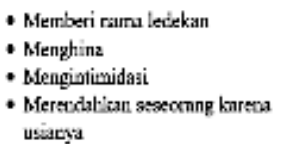 & $\begin{array}{c}4,5,6 \\
7,8 \\
9,10 \\
11,12,13\end{array}$ & $\begin{array}{l}3 \\
2 \\
2 \\
3\end{array}$ \\
\hline
\end{tabular}

Kategorisasi Perilaku Bullying (Y)

\begin{tabular}{cccc}
\hline Kategorl & Skor Interval & Frakuensi & Persentase \\
\hline Rendah & $X<74$ & 13 & $15,7 \%$ \\
Sedang & $74 \leq X<94$ & 57 & $68,6 \%$ \\
Tinggi & $X \geq 94$ & 13 & $15,7 \%$ \\
\hline \multicolumn{2}{c}{ Jumlah } & 83 & $100 \%$ \\
\hline
\end{tabular}

\begin{tabular}{|c|c|c|c|}
\hline Mreugisolasi & $\begin{array}{l}\text { - Menzeyah peqawai mergaksas } \\
\text { kesempatan } \\
\text { - Mengisolnsi secara fisik } \\
\text { - Mengisolasi secara sosial } \\
\text { - Menahon infurmasi }\end{array}$ & $\begin{array}{c}14 \\
15,16,17 \\
18,19 \\
20,21\end{array}$ & $\begin{array}{l}3 \\
2 \\
2\end{array}$ \\
\hline $\begin{array}{l}\text { Beban kerja } \\
\text { yaus } \\
\text { herlelialuma }\end{array}$ & $\begin{array}{l}\text { - Telcaran yang ters mentrus } \\
\text { - Batas rakno yiug tidsk mulgkin } \\
\text { terpersuhi }\end{array}$ & $\begin{array}{c}22 \\
23,24\end{array}$ & $\begin{array}{l}1 \\
2\end{array}$ \\
\hline $\begin{array}{l}\text { Pesbuatan } \\
\text { yans } \\
\text { meayebabkan } \\
\text { ketidakstubilan }\end{array}$ & $\begin{array}{l}\text { - Memberikan tugza yang tidzk } \\
\text { berguna } \\
\text { - P'englapusan tangqung jarab } \\
\text { - Mengingut ulang ketaliatian }\end{array}$ & $\begin{array}{l}25 \\
26,27 \\
28,29\end{array}$ & $\begin{array}{l}2 \\
2\end{array}$ \\
\hline & TOTAL & & 29 \\
\hline
\end{tabular}

Tabel 4.1.1 Blue Print Sebaran Nomor Aitem Skala Perilaku Bullying

Setelah dilakukan uji validitas isi didapatkan 29 aitem yang valid. Dua puluh sembilan aitem tersebut terdiri dari 3 aitem dari aspek ancaman pada status professional, 10 aitem pada aspek ancaman pada pribadi, 8 aitem pada aspek mengisolasi, 3 aitem pada aspek beban kerja yang berlebihan, dan 5 aitem pada perbuatan yang menyebabkan 
ketidakstabilan. Berdasarkan hasil confirmatory analisis factor, semua indikator perilaku bullying di tempat kerja memiliki nilai $\mathrm{p}>0,3$ dengan skor; (1) Berupa ancaman pada status profesional $(0,64) ;(2)$ ancaman pada pribadi $(0,89) ;(3)$ Mengisolasi $(0,89)$; (4) Beban kerja yang berlebihan $(0,87)$ serta; (5) Perbuatan yang menyebabkan ketidakstabilan $(0,55)$. Berdasarkan hasil confirmatory analisis factor tersebut diketahui bahwa indikatorindikator yang ada mampu merefleksikan konstruk laten dari perilaku bullying di tempat kerja. Indikator ancaman pada pribadi dan mengisolasi merupakan indikator yang paling besar dalam mengukur perilaku bullying di tempat kerja dengan nilai 0,89 . [10]

\begin{tabular}{|c|c|c|c|c|c|c|c|}
\hline & & & Estimate & E. & R. & & Label \\
\hline tab & -- & BULLYY & 1,000 & & & & \\
\hline $\mathrm{eb}$ & -- & BULLY & 1,099 & 207 & ,300 & ** & par__1 \\
\hline & -- & BULLY & 2,156 & 404 & ,342 & ** & par_2 \\
\hline $\mathrm{ri}$ & -- & BULLY & 2,860 & 533 & ,360 & ** & par_3 \\
\hline & -.. & BULLY & .686 & 155 & , 436 & ** & par_4 \\
\hline
\end{tabular}

Tabel 4.1.2 Regression Weight : (Group number 1 - Default model)

\begin{tabular}{|c|c|c|c|}
\hline & & & Estimate \\
\hline tab & --- & BULLY &, 547 \\
\hline eb & $\cdots$ & BULLY & 872 \\
\hline so & -- & BULLY & 887 \\
\hline ri & $\cdots$ & BULLY &, 895 \\
\hline & -- & BULLY & ,635 \\
\hline
\end{tabular}

Tabel 4.1.3 Standardized Regression Weights : (Group number 1 - Default model)

Nilai koefisien tersebut membuktikan homogenitas yang sangat baik pada aitemaitem. Aitem pertanyaan atau pernyataan diindikasikan memiliki validitas apabila aitem tersebut memiliki kesesuaian dengan fungsi kuesioner secara keseluruhan, yaitu mengukur konstruk. Untuk menentukan aitem mana yang memiliki validitas yang memadai, para ahli menetapkan minimal besaran koefisien korelasi sebesar 0.5 . Cara lainnya adalah menggunakan Corrected aitem-total correlation (ritd). Teknik ini digunakan jika jumlah aitem yang diuji kurang dari 30 (Azwar, 2003). [8] Teknik ini menentukan besaran koefisien korelasi aitem total dikoreksi sebesar 0.25 atau 0.3 sebagai batas minimal valid tidaknya sebuah aitem (Azwar, 2003). Dari 29 aitem yang di ujikan kepada 83 subjek yang ada terdapat 1 aitem dinyatakan gugur karena tidak mencapai batas minimal yaitu aitem no 19, sehingga hanya terdapat 28 aitem yang valid.

Berdasarkan hasil uji realibilitas dengan alpha cronbach didapatkan hasil koefisien realibilitas sebesar 0,909. Hal ini menunjukkan bahwa alat ukur ini dapat digunakan untuk mengukur perilaku bullying di tempat kerja. Meskipun demikian, alat ukur ini memiliki keterbatasan. Alat ukur ini mungkin perlu dikembangkan lagi dengan subyek yang berbeda-beda karakteristik, misalnya terkait dengan status pekerja dan tempat bekerja. 


\section{Data Hasil Penelitian Skala Perilaku}

\section{Bullying}

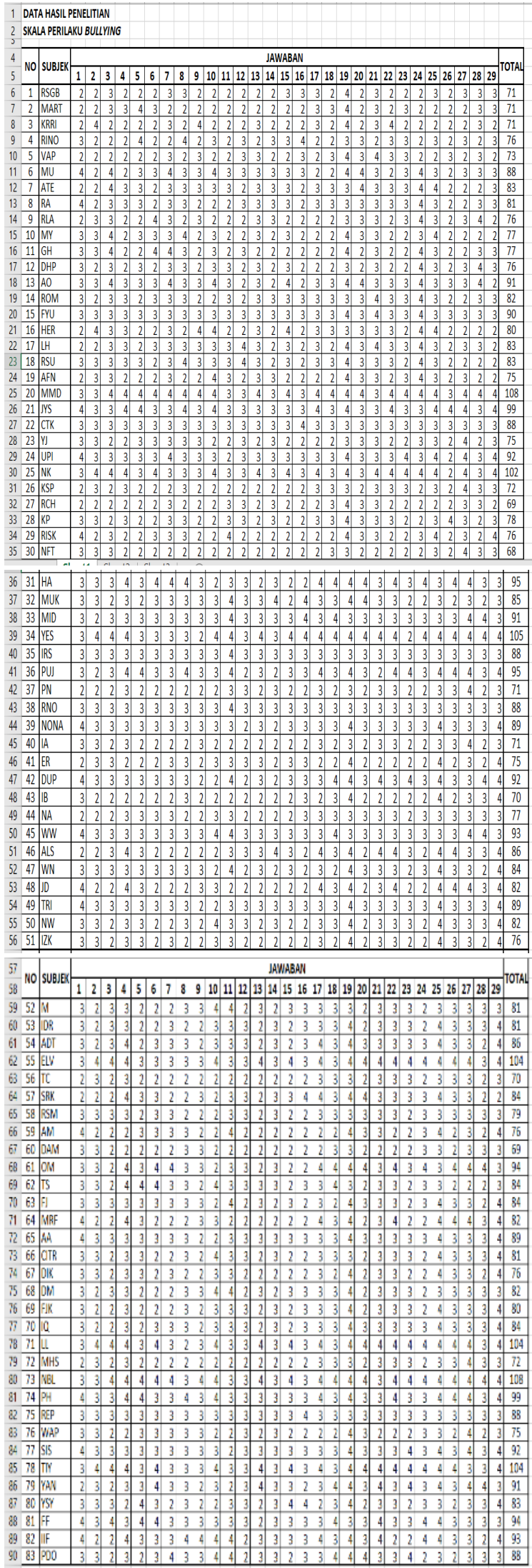

Tabel 4.2.1 Data Hasil Skala Perilaku Bulyying
Berdasarkan confirmatory analisis factor semua 117ronbach117 perilaku bullying di tempat kerja memiliki nilai $\mathrm{p}>0,3$ dengan skor; (1) Berupa ancaman pada status 117ronbach117nal $(0,64)$; (2) ancaman pada pribadi (0,89); (3) Mengisolasi $(0,89)$; (4) Beban kerja yang berlebihan $(0,87)$ serta; $(5)$ Perbuatan yang menyebabkan ketidakstabilan $(0,55)$. Berdasarkan hasil uji realibilitas terhadap butir-aitem didapatkan alpha 117ronbach sebesar 0,909. Nilai koefisien tersebut membuktikan homogenitas yang sangat baik pada aitem-aitem. Analisis faktor dengan exploratory factor analisis menunjukkan nilai Kaiser-Meyer-Olkin (KMO) sebesar $0,934(<0,7)$ dengan nilai signifikansi sebesar 0,000 menunjukkan butiraitem berkorelasi tinggi. [12]

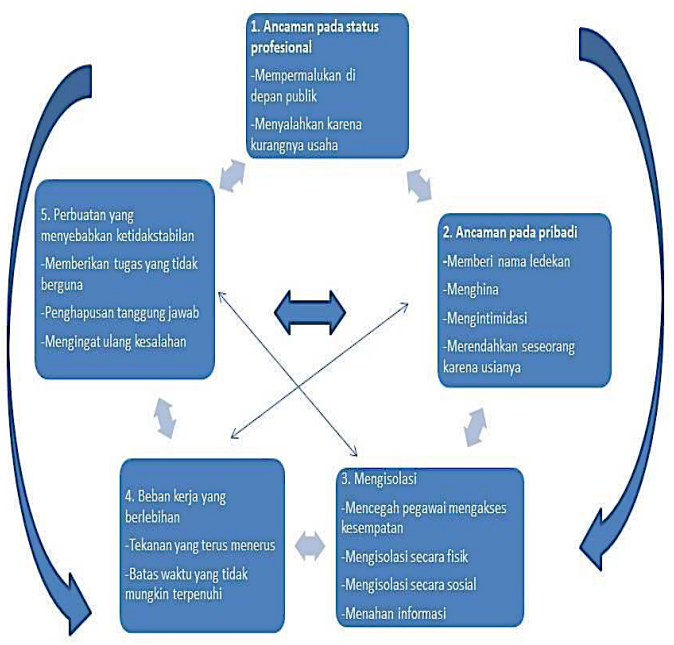

Gambar 2 Proses olah data Analisa SEM

\section{Interface Sistem Pakar}

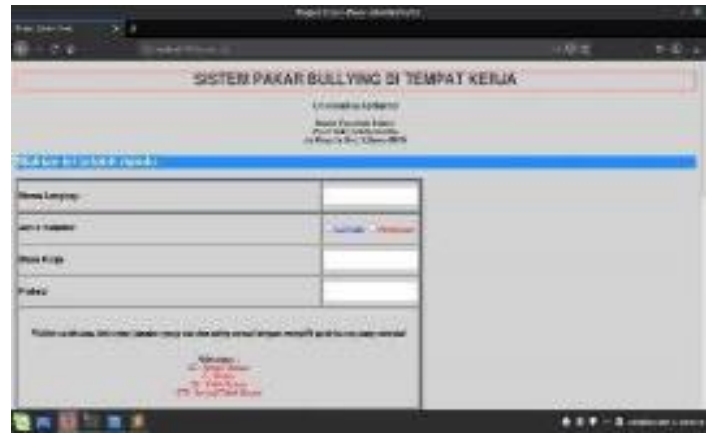




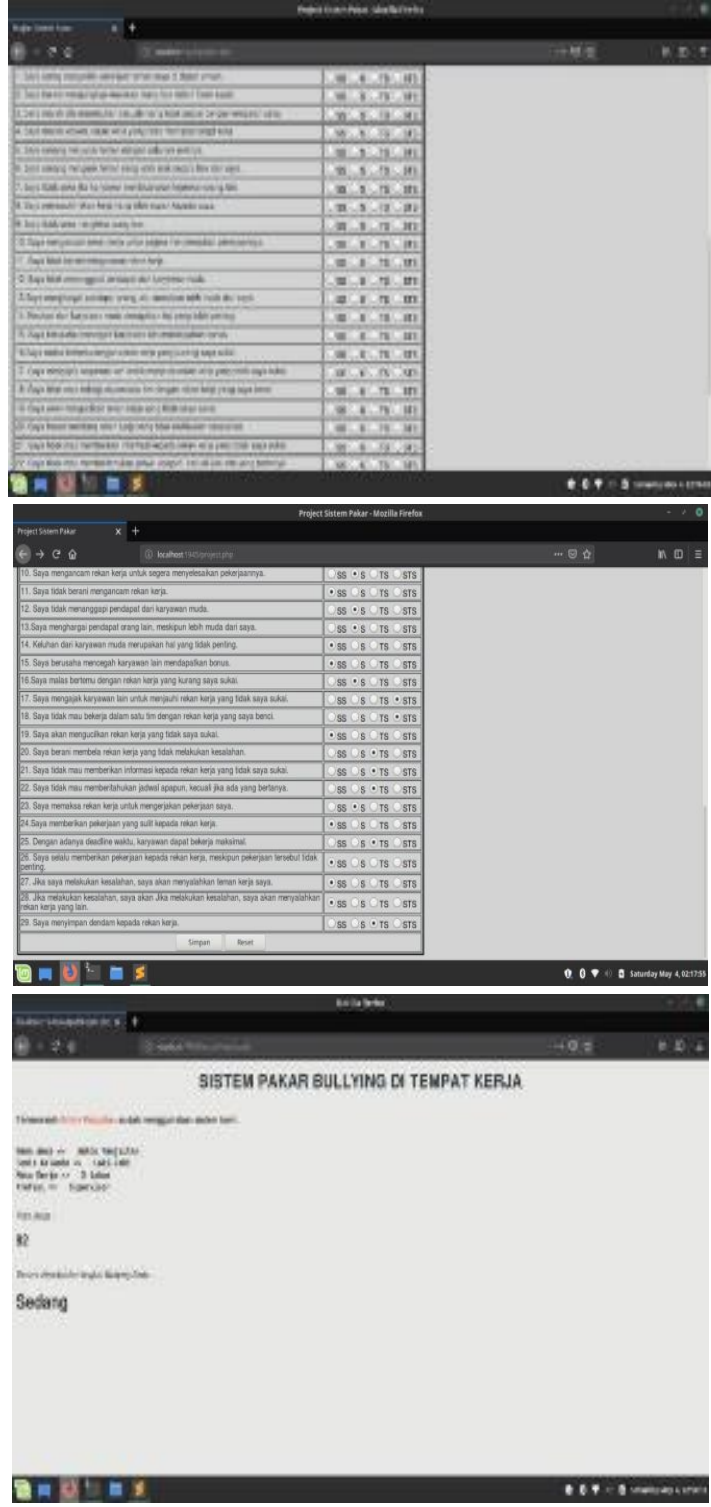

Tabel 3. Tampilan Interface Sistem Pakar
Teknik ini menentukan besaran koefisien korelasi aitem total dikoreksi sebesar 0.25 atau 0.3 sebagai batas minimal valid tidaknya sebuah aitem (Saifuddin Azwar, 2003). Dari 29 aitem yang di ujikan kepada 83 subjek yang ada terdapat 1 aaitem dinyatakan gugur karena tidak mencapai batas minimal yaitu aitem no 19, sehingga hanya terdapat 28 aitem yang valid.

Berdasarkan hasil uji realibilitas dengan alpha cronbach didapatkan hasil koefisien realibilitas sebesar 0,909. Hal ini menunjukkan bahwa alat ukur perilaku bullying daitempat kerja ini dapat digunakan untuk mengukur perilaku bullying di tempat kerja. Meskipun demikian, alat ukur ini memiliki keterbatasan. Alat ukur ini mungkin perlu dikembangkan lagi dengan subyek yang berbeda-beda karakteristik, misalnya terkait dengan status pekerja dan tempat bekerja.

Hasil yang telah diperoleh dimasukan sebagai knowledge expert ke dalam aplikasi web sebagai dasar aturan memprediksi persepsi gender terhadap bullying di tempat kerja melalui forecasting dimensidimensinya, serta faktor usia, masa kerja, dan ragam profesi. Peneliti membuat sistem pakar ini menggunakan metode forward chainning.

\section{DAFTAR PUSTAKA}

Adapun kesimpulan yang dapat di ambil dari penelitian ini adalah nilai koefisien tersebut membuktikan homogenitas yang sangat baik pada aitem-aitem. Aitem pertanyaan atau pernyataan diindikasikan memiliki validitas apabila aitem tersebut memiliki kesesuaian dengan fungsi kuesioner secara keseluruhan, yaitu mengukur konstruk. Untuk menentukan aitem mana yang memiliki validitas yang memadai, para ahli menetapkan minimal besaran koefisien korelasi sebesar 0.5.

Cara lainnya, adalah menggunakan Corrected aitem-total correlation (ritd). Teknik ini digunakan jika jumlah aitem yang diuji kurang dari 30 (Saifuddin Azwar, 2003).
[1] S. Einersen, H. Hoel, D. Zapf and C. L. Cooper, Bullying and harassment in the workplace: Developments in theory, reseach, and practice, Forida: Crc Press, 2010 .

[2] A. T. Karabulut, "Bullying: harmful and hidden behavior in organizations," Procedia - Social and Behavioral Sciences, vol. 229, no. 5, pp. 4-11, 2016.

[3] P. EJ, L. M and P. M, "Instruments and Taxonomy of Workplace Bullying in 
Health Care Organizations," Asian Nurs

Res (Korean Soc Nurs Sci), vol. 11, no. 4, pp. 237-245, 2017.

[4] A. BK, K. B. K and T. LA, "Workplace bullying, perceived job stressors, and psychological distress: Gender and race differences in the stress process.," Soc Sci Res, vol. 65, no. 10.1016, pp. 210221, 2017.

[5] A. S. Rusydiana and A. Devi, Analytic Network Process; Pengantar Teori dan Aplikasi, Bogor: Smart Publishing, 2012.

[6] N. Merlina and R. Hidayat, Perancangan Sistem Pakar, Yogyakarta: Ghalia Indonesia, 2012.

[7] W. Budiharto and S. Derwin, Artificial Intelligence - Konsep dan Penerapannya, Yogyakarta: Andi Offset, 2014.

[8] M. Arhami, Konsep Dasar Sistem Pakar, Yogyakarta: Andi Publisher, 2005.

[9] A. A. Putra and T. Rahayuningsih, "VALIDITAS KONSTRUK PENGUKURAN PERILAKU BULLYING," Psychopolytan, vol. I, no. 1, pp. 54-60, 2017.

[10] H. Cowie, P. Naylor, I. Rivers, P. K. Smith and B. Pereira, "Measuring workplace bulying," Agress. Violent Behave, vol. 7, no. 1, pp. 33-51, 2002.

[11] S. Azwar, Metode Penelitian, Yogyakarta: Pustaka Pelajar, 2003.

[12] M. B. Nielsen and S. V. Einarsen, "What we know, what we do not know, and what we should and could have," Aggression and Violent Behavior, vol. 42, no. 4, pp. 71-83, 2018. 